\title{
Behavior and diet of the Critically Endangered Eulemur cinereiceps in Manombo forest, southeast Madagascar
}

Fidimalala B. Ralainasolo', Jonah H. Ratsimbazafy" and Nancy J. Stevens

\author{
Correspondence: \\ Nancy J. Stevens \\ Department of Biomedical Sciences, 228 Irvine Hall \\ Ohio University, Athens, OH 45701, USA \\ E-mail: stevensn@ohio.edu
}

\begin{abstract}
Manombo Special Reserve is a parcel of rainforest along the southeastern coast of Madagascar, containing eight lemur species, including the White-collared brown lemur (Eulemur cinereiceps [Eulemur albocollaris]). Following a drastic cyclone in the region in January of 1997 , the population of E. cinereiceps at Manombo was reduced by half. Results indicate that individuals of this critically endangered species at Manombo consume a total of 54 plant species belonging to 24 families, with over two-thirds of the diet comprised of ripe and unripe fruits. White-collared brown lemurs also opportunistically feed on novel food items and invasive plants in their recovering habitat. We report the first record of $E$. cinereiceps consuming a shelf fungus species growing on invasive trees. During feeding, lemurs tore pieces of the fungus from the trees with their hands and mouth (chewing cycle duration mean 0.28 s; SD 0.01). White-collared brown lemurs also consumed spicy fruits of a non-native plant species (Aframomum angustifolium) growing in highly disturbed open areas. Feeding bouts typically began by stripping away the outer covering with the anterior dentition, with pulp and seeds then consumed (chewing cycle duration mean $0.22 \mathrm{~s}$; SD 0.005). This is the first record of consumption of either of these resources for any lemur species at Manombo. Ability to feed on items like A. angustifolium may permit E. cinereiceps to avoid competition with other species in this highly degraded forest environment.
\end{abstract}

\section{RÉSUMÉ}

La Réserve Spéciale de Manombo est un fragment de forêt dense humide de basse altitude et située le long de la côte sud-est de Madagascar. Cette partie de forêt abrite au total huit espèces de lémuriens, y compris le Lémur à collier blanc (Eulemur cinereiceps [Eulemur albocollaris]). Le passage dramatique du cyclone Gretelle dans la région en janvier 1997 a réduit de moitié la taille de la population d'E. cinereiceps dans sa zone de distribution. Les résultats des études effectuées sur les individus restants de cette espèce, qui est classée comme Gravement Menacée, permettent d'énumérer un total de 54 espèces de plantes appartenant à 24 familles qui sont consommées par l'espèce. D'autre part, deux tiers du régime ali- mentaire d'E. cinereiceps sont représentés par des fruits mûrs ou non. Le Lémur à collier blanc consomme occasionnellement une quantité assez importante de plantes envahissantes pour assurer ses besoins nutritifs, ce qui n'est pas habituel dans I'histoire naturelle de la vie des lémuriens. La présente étude constitue également la première observation de consommation d'une espèce inconnue de champignon par les représentants $\mathrm{d}^{\prime} E$. cinereiceps. Dans le présent cas, ledit champignon venait juste de pousser sur un pied mort de Cecropia peltata, une espèce allogène et envahissante de la région. Durant la prise de nourriture, l'animal a arraché des morceaux du champignon sur l'arbre mort avec la main et puis la bouche. La partie consommée a été mâchée par l'animal pendant une période de 0,28 s. Le Lémur à collier blanc consomme aussi des fruits épicés d'une espèce de plante allogène (Aframomum angustifolium) qui ne pousse que dans des zones ouvertes et extrêmement dégradées. La prise de nourriture sur cette espèce de plante commence par l'enlèvement de la partie dure du fruit, pour cela I'animal utilise ses dents antérieures très puissantes, puis il tire soigneusement en même temps avec ses dents et sa langue la partie charnue et les graines. Cette prise de nourriture s'effectue pendant une période d'environ 0,22 s. C'était la première fois dans l'histoire des lémuriens de Manombo que des observations ont été effectuées sur un animal en train de manger des espèces de plantes inhabituelles. L'aptitude de manger des espèces de plantes telle que $A$. angustifolium pourrait permettre à E. cinereiceps d'éviter la compétition avec les autres espèces de lémuriens vivant dans cet environnement dégradé.

KEYWORDS: White-collared brown lemur, feeding behavior, habitat disturbance, invasive species, chewing cycle

\section{INTRODUCTION}

Manombo Special Reserve is a parcel of rainforest along the southeastern coast of Madagascar, containing eight lemur species, including the Critically Endangered Eulemur cinereiceps. Notably, this taxon has been featured on the World's 25 Most Endangered Primates list since 2004, and was until recently commonly referred to as Eulemur albocollaris (e.g. Mittermeier et al. 2006). Recent studies suggest that the species name cinereiceps 


\section{VOLUME 3 ISSUE 1

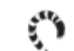 DECEMBER 2008 MADAGASCAR \%, CONSERVATION \& DEVELOPMENT}

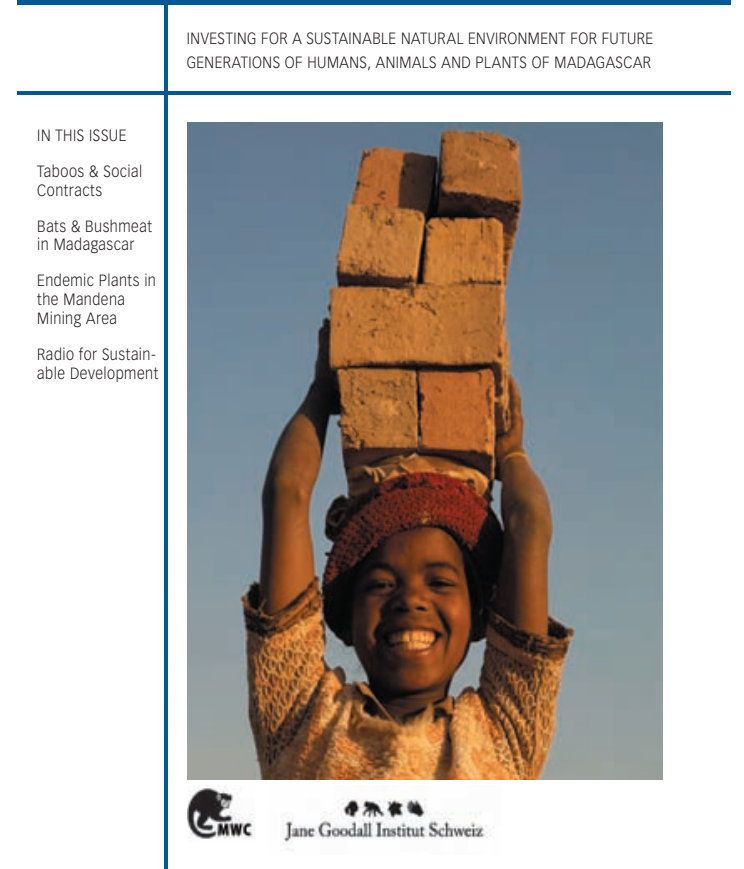

Madagascar Conservation \& Development is the journal of Madagascar Wildlife Conservation (MWC) and the Jane Goodall Institute (JGI Switzerland). It is produced in these institutions' own responsibility.

All the Issues and articles are freely available at http://www.mwc-info.net/en/services/journal.htm

Contact Journal MCD

info@journalmcd.net for general inquiries MCD funding@journalmcd.net for supporting the journal

Journal Madagascar Conservation \& Development Institute and Museum of Anthropology University of Zurich

Winterthurerstrasse 190

$\mathrm{CH}-8057$ Zurich, Switzerland

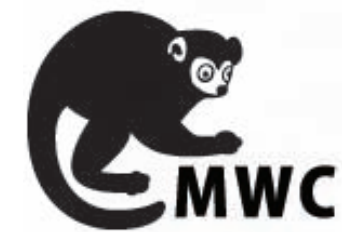

contact@mwc-info.net for general inquiries

Postfach 2701

CH-8021 Zürich, Switzerland

Logement 11, Cité Andohaniato Antananarivo 101, Madagascar

info@janegoodall.ch for general inquiries JGI

\section{$2 \pi$}

Jane Goodall Institut Schweiz
Switzerland

Postfach 2807

8033 Zürich, Switzerland 
has taxonomic priority and justify adopting such nomenclature at this time (Johnson et al. 2008 and references therein). For the sake of continuity with most of the published literature on the taxon we continue to use the common name White-collared brown lemur herein. Due to the extreme vulnerability of the White-collared brown lemur, it is imperative to document and understand the ecological conditions necessary for its survival.

Eulemur cinereiceps is a medium-sized lemur, with a body mass of about $2-2.5 \mathrm{~kg}$. The species is sexually dichromatic; the male is generally dark with a white beard, whereas the female is rufous in color (Figure 1). White-collared brown lemurs live in social groups ranging in size between three and nine individuals (Mittermeier et al. 2004). Eulemur cinereiceps tends to be a frugivorous species, with a diet consisting mainly of fruit, and with a smaller proportion of the diet including leaves (mature and young), nectars and fungi (Johnson 2000). Like other Eulemur species, White-collared brown lemurs are cathemeral, or active during both day and night time, with the duration of nocturnal activity depending upon both season and food availability (Mittermeier et al. 2006). Eulemur cinereiceps exhibits fission-fusion social patterns and tends to be organized into multi-male / multi-female groups (Mittermeier et al. 2006). As in other primates, troop fusion occurs primarily during the period of abundance of natural resources in the forest, whereas troops undergo fission at times of food scarcity, such that smaller groups have sufficient access to resources to avoid spending energy in social conflicts (Ratsimbazafy 2002). Following cyclone Gretelle in the region in January of 1997, the population of $E$. cinereiceps at Manombo was reduced by half (Ratsimbazafy 2002). The habitat was drastically altered, with more than $90 \%$ of the autochthonous trees destroyed, decreasing availability of many of the plant species preferred by E. cinereiceps (Ratsimbazafy 2002). This study demonstrates that perhaps in addition to altering group size in disturbed forest parcels, individuals of this critically-endangered species have other strategies for overcoming food scarcity, such as opportunistic feeding on novel food items and invasive plants in their recovering habitat.

MANOMBO FOREST Located along the southeastern coast of Madagascar, the forest of Manombo is a good site to study the behaviour of wild E. cinereiceps. Manombo is accessible throughout the year, and in addition to providing insights into the effects of habitat disturbance upon lemur biology, it offers a convenient comparison between forest areas

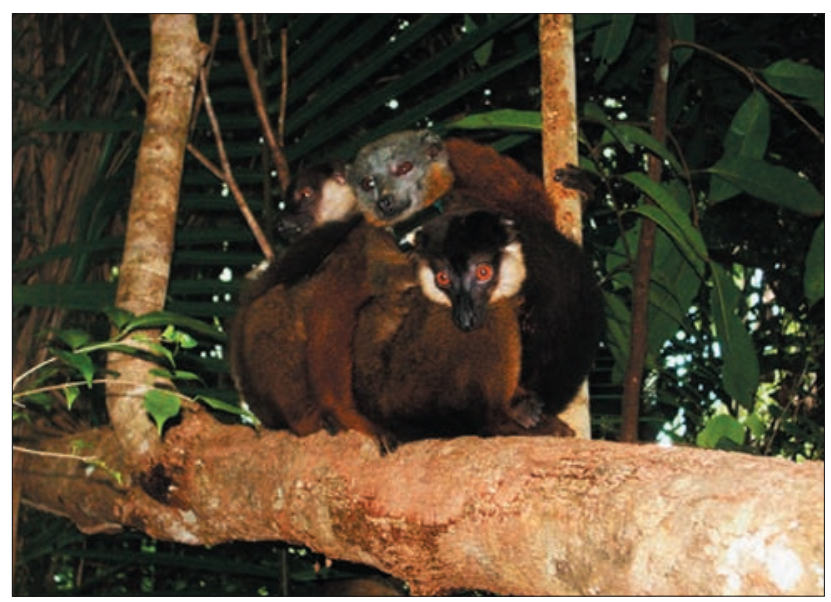

FIGURE 1. Eulemur cinereiceps, two males and one female (photo by F. Ralainasolo). both with and without a strict conservation statute in place. The total area of Manombo forest is about 15,000 ha. The forest contains two main vegetation types: humid evergreen forest in altitudes between 40 and $120 \mathrm{~m}$, and littoral forest lying at lower altitudes along the white coastal sands (Moat and Smith 2007). The present study focused on low altitude humid forest parcels encompassing a total of 13,000 ha (Figure 2). One parcel of humid dense forest (2,800 ha) is termed Manombo Special Reserve (SR), and is administrated by the ANGAP (National Association for the Management of the Protected Areas). The other parcel $(10,000$ ha) is called Manombo Classified Forest (CF), and is managed by the MEFT (Ministère de I'Environnement, des Forêts et du Tourisme - Ministry of Environment, Forests and Tourism) administered locally by the DREFT (Direction Régionale de l'Environnement, des Forêts et du Tourisme - Interregional Direction of Environment, Forests and Tourism). Although each portion of forest is considered protected by the government, the specific regulations governing forest use differs. For example, access to the SR is restricted, and activities like hunting and tree cutting are considered strictly illegal. In contrast, within the $\mathrm{CF}$, use of timber and non-timber forest products is permitted under a policy of sustainable use. Despite the differing laws established for the good management of both portions of forests, each remains under pressure. Among the threats to longterm forest survival include slash and burn agriculture, logging, hunting and unsustainable use of secondary products. Without viable alternatives, such resources are needed by local villagers in order to survive. Because of the legislation and enforcement practices in place, unsustainable activities are more pronounced in the Classified Forest.

MANOMBO FOREST STRUCTURE Since the two portions

of forests (SR and CF) are geographically so close to one another, few differences would be expected in their forest structure. Results of preliminary studies demonstrate that aspects of the overall structure and species composition of the two parcels of forest are indeed similar. A comparison of vegetation structure and composition was conducted in a one hectare botanical plot in each portion of forest. Variables recorded included plant species, tree height and DBH (Diameter at Breast Height). Results indicate that the two parcels (SR and CF) have a $9.8 \mathrm{~m}$ and 9.7 $\mathrm{m}$ medium tree height, respectively. Average $\mathrm{DBH}$ of the trees is about $8.2 \mathrm{~cm}$ for the SR and $7.7 \mathrm{~cm}$ for the CF. There were 2,567 plants recorded at the SR, as compared with 2,978 at the CF. Plant species belong to 47 families, the most common of which include Euphorbiaceae, Arecaceae, Cecropiaceae, Convallariaceae, Sapindaceae, Rubiaceae, Malvaceae, Lauraceae, Erythroxylaceae, Ebenaceae, Myrtaceae, Myristicaceae, and Salicaceae.

BEHAVIORAL SAMPLING METHODS Behavioral data collection took place between October 2006 and January 2007, and again from August to December 2007 to sample both the wet and dry seasons at Manombo. Behavioral observations were conducted between 0600-1700h each day, for a total of 517 hours, over 62 days. Although Eulemur may also feed at night (Donati et al. 2007), study observations were limited to daylight hours as visibility of food items was not possible in the dark. Two main data collection methods were employed: FR conducted instantaneous sampling at an interval of once per 5 minutes (Altman 1974), and a field assistant also collected data continuously. During the survey, FR conducted focal animal sampling, changing the focal individual every two hours. Data were recorded 


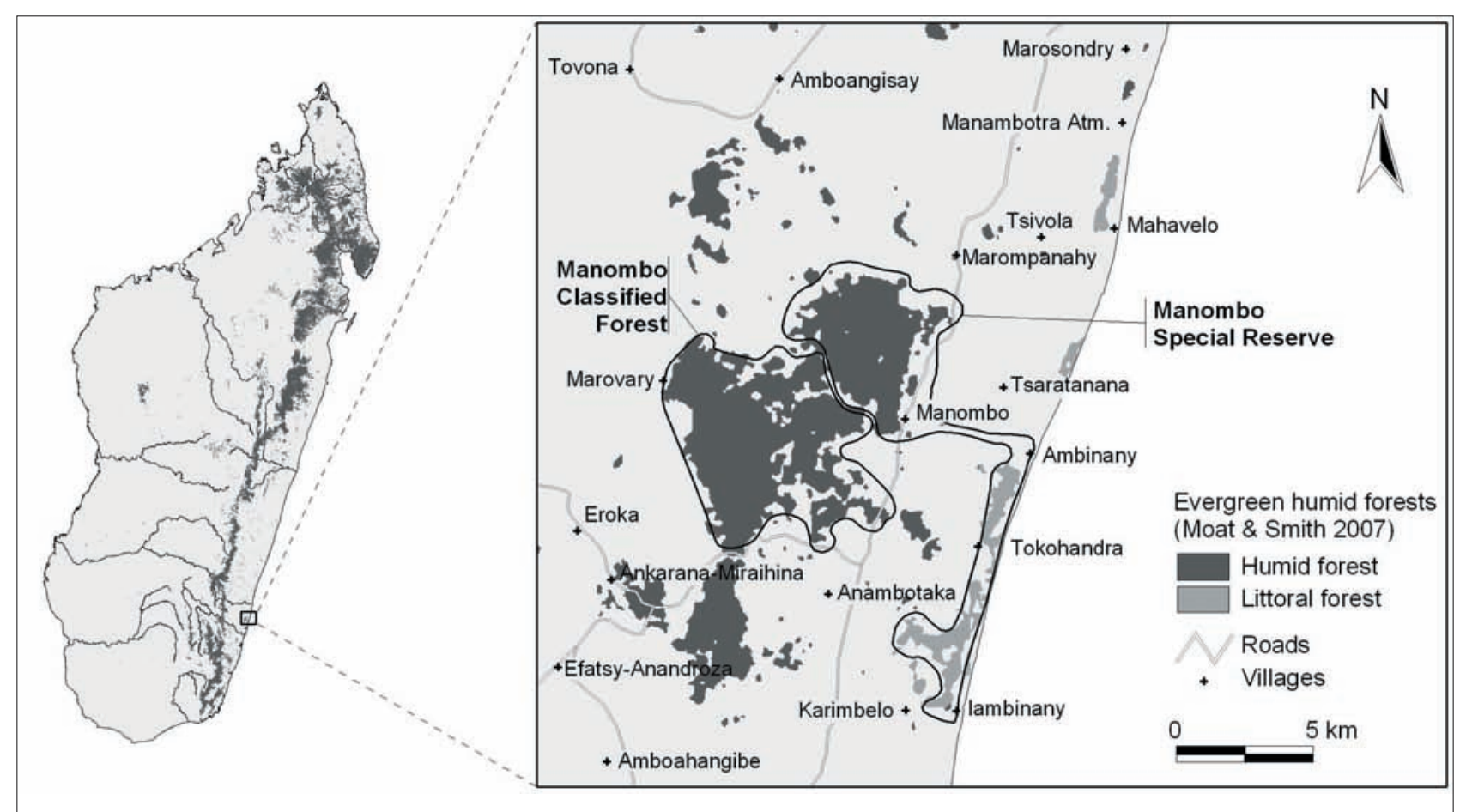

FIGURE 2. Location of the study area.

on all behaviours exhibited by the focal animal, in this case the behaviours are categorised into four main types: Resting (remaining in one place), Feeding (with the type of food item recorded), Moving (travelling or otherwise changing position), and lastly Social (contact between two or more individuals).

We studied two groups of animals in the Classified Forest and two groups of animals in the Special Reserve, and recorded the frequency and duration of time spent feeding on each plant species, and estimated the distance in meters between the ground and the position of the animal in the feeding tree. Dietary data included both the plant species that the animal fed upon, in addition to the plant part consumed. Plant parts were identified using a binocular $(8 \times 10)$, whereas the duration of time spent feeding on a given food item was estimated using a chronometer. Plant samples were collected for each species of plants that could not be readily identified by our team. Those samples are undergoing identification by specialists at PBZT (Parc Botanique et Zoologique de Tsimbazaza).

In addition, animals were opportunistically filmed during feeding on novel food items in order to compare chewing cycle durations. Chewing cycle duration relates to a number of properties of food items, for example, cycle durations can differ with bolus size or during times that food is grasped / manipulated (e.g. Dötsch 1986). Subjects were videotaped following methods described in Stevens (2003) and Stevens et al. (2006a and 2006b), using Sony DSC-H handheld digital video cameras positioned at a distance of $5 \mathrm{~m}$ from the study subjects to reduce parallax. Frame rates were optimized to catch rapid movements by splitting $30 \mathrm{~Hz}$ fields to achieve $60 \mathrm{~Hz}$, and shutter speeds were set to reduce motion blur. Video sequences were imported into Peak Motus (version 9.0) and chewing cycle durations were calculated. The chewing cycle rate was defined as the duration of time (in seconds) between successive complete jaw closures.

\section{RESULTS}

ACTIVITY PATTERNS Activity patterns of E. cinereiceps are depicted in Figure 3. In the majority of the activity budget observations, the study animals were resting (over $40 \%$ of the time) or engaging in social behaviors (over $30 \%$ of the time). Feeding and traveling each constituted about $12 \%$ of the activities recorded (Figure 3 ). Note that animal visibility did not present a significant challenge during the study.

DIETARY COMPOSITION As expected, more than $67 \%$

of the foods eaten by $E$. cinereiceps were ripe or unripe fruits. White-collared brown lemurs also consumed a considerable quantity of leaves. During the survey, a total of 54 plant species belonging to 24 families were consumed by E. cinereiceps. Table 1 lists the items consumed by E. cinereiceps during the wet and dry seasons. Notably, only 14 food species were consumed during the dry season, compared with 51 food species consumed during the wet season. A total of 11 food species were consumed during both wet and dry seasons. Figure 4 depicts just a few of the species consumed by E. cinereiceps. Although

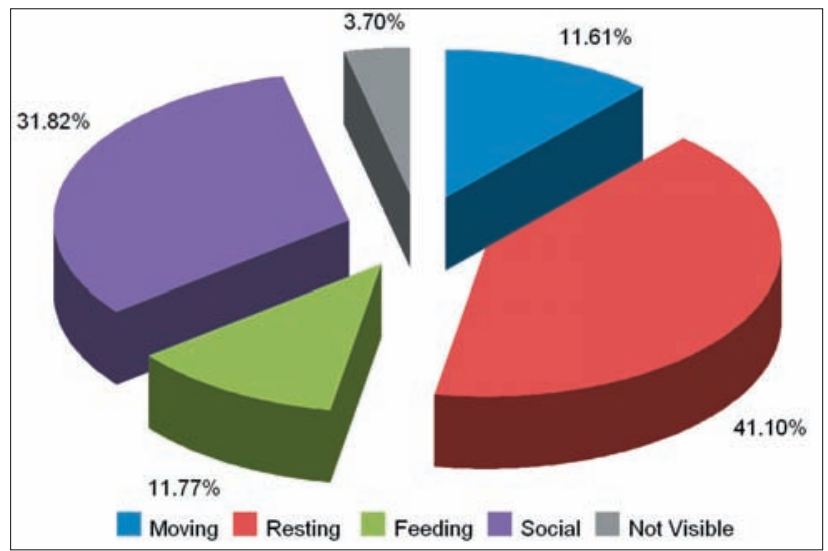

FIGURE 3. Activity budget of Eulemur cinereiceps. 
TABLE 1. List of plant species consumed by Eulemur cinereiceps. Abbreviations as follow: RF (ripe fruit), UF (unripe fruit), YL (young leaves), ML (mature leaves), FL (flowers), NEC (nectar), F (fungus), D (dry season), W (wet season).

\begin{tabular}{|c|c|c|c|c|}
\hline Family & Scientific name & Vernacular name & Part consumed & Season consumed \\
\hline Acanthaceae & Mendocia flagellaris & Vahy & $\mathrm{RF}, \mathrm{YL}, \mathrm{ML}$ & $\mathrm{D}, \mathrm{W}$ \\
\hline Anisophylleaceae & Anisophyllea sp & Hazomamy & UF & W \\
\hline Annonaceae & Ambavia sp & Robavy & $\mathrm{YL}, \mathrm{RF}$ & W \\
\hline Apocinaceae & Landolphia platyclada & Vahateso & RF & W \\
\hline Araliaceae & Schefflera & Vatsilambato & UF & w \\
\hline Arecaceae & Dypsis sp & Vonitra & $\mathrm{RF}$ & $\mathrm{D}, \mathrm{W}$ \\
\hline Asteropeiaceae & Asteropeia sp & Hazoseha & & W \\
\hline Celastraceae & Astrocassine $\mathrm{sp}$ & Maronono & $\mathrm{FL}$ & W \\
\hline Cecropiaceae & Cecropia peltata & Tanatana & UF,RF & $\mathrm{D}, \mathrm{W}$ \\
\hline Clusiaceae & Symphonia sp & Ditsaka & RF & W \\
\hline Erythroxylaceae & Erythroxylum sphaeranthum & Menahihy & $\mathrm{YL}$ & W \\
\hline Euphorbiaceae & $?$ & Baby & RF & $\mathrm{D}$ \\
\hline Euphorbiaceae & Vepris sp & Kalavelo & $\mathrm{ML}$ & W \\
\hline Euphorbiaceae & Cleistanthus bovinianus & Maroampotony & YL & W \\
\hline Euphorbiaceae & Macaranga obovata & Mokarana & UF,RF & W \\
\hline Fabaceae & Albizia sp & Ambilazo & $\mathrm{YL}$ & W \\
\hline Fabaceae & Cynometra sp & Variotra & $\mathrm{YL}$ & $\mathrm{D}$ \\
\hline Linaceae & Hugonia sp & Vahemavo & RF & W \\
\hline Malvaceae & Dombeya sp & Hafotra & UF,RF & $D, W$ \\
\hline Menispermaceae & Burasaia madagascariensis & Masomposaina & $\mathrm{RF}$ & W \\
\hline Moraceae & Ficus sp & Amota & RF & $\mathrm{D}, \mathrm{W}$ \\
\hline Moraceae & Antiaris sp & Ampa & $\mathrm{RF}$ & $\mathrm{D}, \mathrm{W}$ \\
\hline Moraceae & Ficus sp & Apalimaraha & $\mathrm{RF}$ & $W$ \\
\hline Moraceae & Ficus sp & Haragny & RF & $\mathrm{D}, \mathrm{W}$ \\
\hline Moraceae & Trilepisium boivinianum & Kivozo & RF & W \\
\hline Moraceae & Ficus reflexa & Laza & RF & $\mathrm{D}, \mathrm{W}$ \\
\hline Moraceae & Micronychia sp & Haraseha & $\mathrm{RF}, \mathrm{ML}$ & W \\
\hline Myrtaceae & Syzygium emirnensis & Rotra & $\mathrm{YL}$ & $w$ \\
\hline Oleaceae & Noronhia myrtoides & Tsilaitra & UF & W \\
\hline Pandanaceae & Pandanus sp & Tsirika & $\mathrm{RF}$ & W \\
\hline Rubiaceae & Mussaenda arcuata & Anandaingo & UF & W \\
\hline Malvaceae & Dombeya sp & Valotra & $\mathrm{YL}$ & W \\
\hline Salicaceae & $?$ & Fotsakara & RF & $W$ \\
\hline Salicaceae & Homalium sp & Hazofotsy & UF & W \\
\hline Sapindaceae & Macphersonia gracilis & Marombody & $\mathrm{YL}$ & W \\
\hline Sapindaceae & Macphersonia madagascariensis & Sanira & RF & W \\
\hline Sapotaceae & Sideroxylon sp & Aboladitra & RF & $\mathrm{D}$ \\
\hline Sapotaceae & Labramia louvelii & Nato & RF,UF & $\mathrm{D}, \mathrm{W}$ \\
\hline Sapotaceae & Faucherea sp & Natoboaka & RF & W \\
\hline Sapotaceae & Chrysophyllum boivinianum & Rehiaka & $\mathrm{YL}$ & W \\
\hline Sphaerosepalaceae & Rhopalocarpus sp & Tandria & $\mathrm{YL}$ & $w$ \\
\hline Strelitziaceae & Ravenala madagascariensis & Ravinala & NEC & W \\
\hline Verbenaceae & Lantana camara & Redriaka & UF,RF & $\mathrm{D}, \mathrm{W}$ \\
\hline Zingiberaceae & Aframomum sp & Longoza & RF & W \\
\hline$?$ & $?$ & Angoto & RF & W \\
\hline$?$ & $?$ & Fotsignana & RF & W \\
\hline$?$ & $?$ & Lalotsivoatoa & UF & W \\
\hline$?$ & $?$ & Fungus indet. & & $\mathrm{D}, \mathrm{W}$ \\
\hline$?$ & $?$ & Tendrokazo & UF,RF & W \\
\hline$?$ & $?$ & Vahapiso & RF & $w$ \\
\hline$?$ & $?$ & Vahimatavy & $\mathrm{ML}$ & w \\
\hline$?$ & $?$ & vandremba & $\mathrm{ML}, \mathrm{YL}$ & W \\
\hline$?$ & $?$ & voalatakakoho & RF & W \\
\hline$?$ & $?$ & Voasingiry & UF,RF & W \\
\hline
\end{tabular}



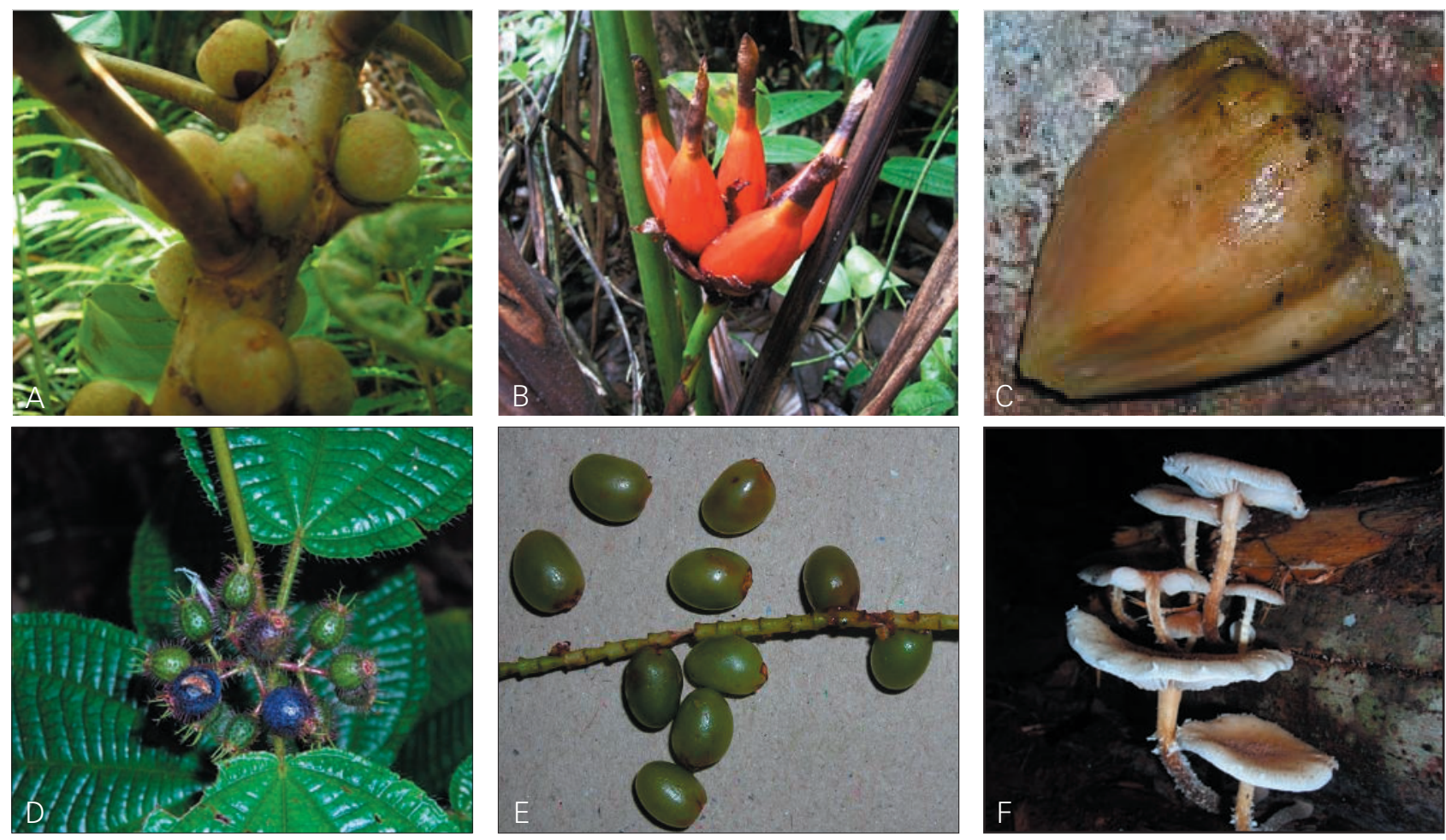

FIGURE 4. Common dietary items of Eulemur cinereiceps, A) Ficus sp., B) Aframomum angustifolium, C) Pandanus sp., D) Clidemia hirta, E) Cynometra sp., F) unidentified fungus.

E. cinereiceps is considered a frugivorous species (Mittermeier et al. 2006), individuals also included leaves, nectars and fungi in their diets. Notably, White-collared brown lemurs did not eat the same parts of each plant species (Figure 5).

CONSUMPTION OF NON-NATIVE FOOD ITEMS Of the 54

plant species eaten by White-collared brown lemurs, four are classified as introduced species, and non-native plants constituted over $23 \%$ of the feeding records of these endangered lemurs. Notably, this is the first record of $E$. cinereiceps consuming an undetermined fungus species growing on the trunks of dead Cecropia peltata (Cecropiaceae) trees Interestingly, Cecropia is an invasive plant that is common in disturbed forest areas (Weber 2003). During feeding lemurs tore pieces of the whitish-yellow fungus from the trees with their hands and mouth. The fungus appeared to be fairly resistant to manual tearing, and pieces were consumed using chewing cycles of over one quarter of a second in duration (mean $0.28 \mathrm{~s}$; SD 0.01). White-collared brown lemurs were also observed consuming spicy fruits of a non-native plant species (Aframomum angustifolium Zingiberaceae). Feeding bouts typically began by holding the fruit with both hands and stripping away the outer covering with the anterior dentition. The pulp and seeds were then rapidly consumed, with shorter chewing cycle duration (mean $0.22 \mathrm{~s} ;$ SD 0.005). After consuming the contents, they discarded the remaining outer covering, and quickly licked their fingers and palms. This is the first record of consumption of either of these resources for any of the lemur species at Manombo, and differences in chewing cycle duration may result from differences in the sizes of bites taken, as well as differences in manipulation / handling of the two types of food items during consumption.

\section{DISCUSSION}

The passage of cyclone Gretelle in 1997 destroyed $75 \%$ of the trees in the special Reserve and $50 \%$ of the trees in the Classified Forest (Ratsimbazafy 2002). Overall, the forest of Manombo was severely damaged, with more than $90 \%$ of the autochthonous trees destroyed (Ratsimbazafy 2002). Population sizes of lemur species inhabiting the forest were reduced by half (Ratsimbazafy 2002). It is likely that for a time, resource availability at Manombo was insufficient to support the previous population size, although evidence is mounting that population is now recovering (S. Johnson, pers. comm.). The location of Manombo in southeastern Madagascar renders it subject to frequent cyclone activity, so it is likely that the lemur fauna residing in this forest have been obliged to adapt to cyclical challenges in habitat quality. Our observations reveal that the Critically Endangered Eulemur cinereiceps currently

FIGURE 5. Proportions of different plant parts consumed by Eulemur cinereiceps.

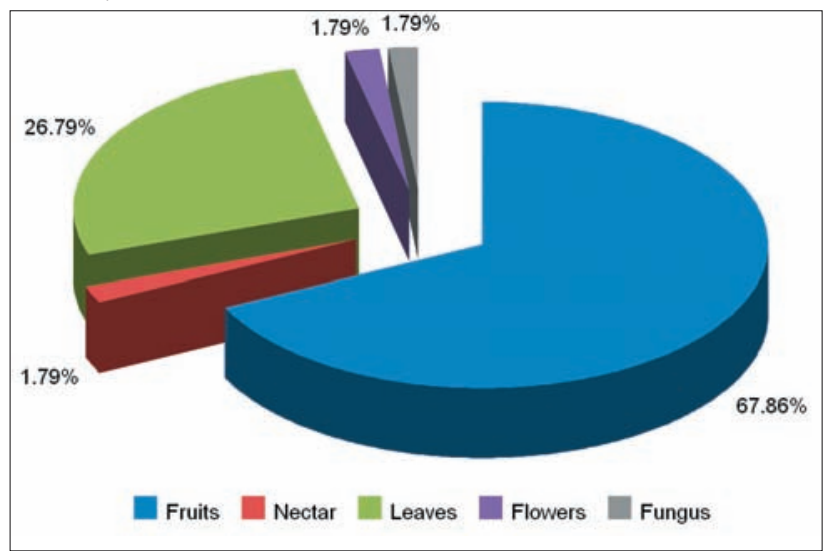


adopts important strategies to overcome food scarcity by taking advantage of invasive species.

Eulemur cinereiceps at Manombo were observed spending up to $25 \%$ of their feeding time opportunistically consuming non-native plant and fungus species in their recovering habitat. This report constitutes the first record of $E$. cinereiceps consuming an undetermined fungus species that grows on the trunks of dead Cecropia peltata trees. Notably, Cecropia is one of the non-native species at Manombo, indicating that introduced vegetation may provide a high proportion of fallback food opportunities in altered habitats. White-collared brown lemurs were also observed consuming spicy fruits of another non-native plant species (Aframomum angustifolium) that grows in a highly disturbed, open area in the forest. Feeding on items such as A. angustifolium is likely to enable E. cinereiceps to cope with habitat destruction, and perhaps in part to avoid competition with other lemurs such as Varecia for native plants in this highly disturbed humid forest habitat. The plant species consumed by Varecia and E. cinereiceps at Manombo overlaps by as much as 75\% (Ratsimbasafy, pers. obs.). To date, varecia has not been observed to feed on A. angustifolium.

\section{CONCLUSIONS}

Habitat loss due to natural and anthropogenic causes presents a major challenge for the conservation of endangered Malagasy faunas. Cyclical storms can drastically alter habitats of animals with low population sizes that are already on the brink of extinction, rendering their chances of long-term survival vanishingly slim. The situation is complicated by the fact that local communities also rely on forest resources for survival. Animals that are capable of taking advantage of a broad range of dietary resources, including plant species introduced by humans, may obtain an edge in surviving during times of food scarcity. White-collared brown lemurs at Manombo spend over a fifth of their feeding time eating plant parts of three introduced species - Lantana camara Verbenaceae, Aframomum sp. and Cecropia peltata. Moreover, consumption of a fungus that grows on the trunk of dead Cecropia peltata constitutes an additional component of the diet. The ability to feed on items such as fungi and spicy fruits of Aframomum angustifolium may permit Eulemur cinereiceps to avoid competition with other species in this highly degraded forest environment. Such dietary flexibility and opportunistic behaviour may prove to be the key to survival for this critically endangered lemur on an ever-changing and often challenging landscape.

\section{ACKNOWLEDGMENTS}

We thank the following people and organizations for assistance in this study: our field guides Kosinisy, Faly Razafy, Tranga François Ramarolahy, and Tsilefa; The Ministère de I'Environnement, des Forêts et du Tourisme, and ANGAP (Association Nationale pour la Gestion des Aires Protégées) for research permits and logistical assistance; ANGAP agent, Salvador; and the research teams of Dr. Ed Louis and Dr. Steig Johnson. Two anonymous reviewers provided input that improved the manuscript. We thank Steve Howard for his support through the African Studies Program, Center for International Studies, Ohio University. Partial funding for kinematics was provided by the Ohio University College of Osteopathic Medicine. We especially recognize the local community in Manombo for whom the forest makes all the difference.

\section{REFERENCES}

Altmann, J. 1974. Observation study behaviour: sampling methods. Behaviour 49: 227-267.

Donati, G., Bollen, A., Borgognini-Tarli, S. M., Ganzhorn, J. U. 2007. Feeding over the 24-h cycle: dietary flexibility of cathemeral collared lemurs (Eulemur collaris). Behavioral Ecology and Sociobiology 61: 1237-1251.

Dötsch, C. 1986. Mastication in the musk shrew, Suncus murinus (Mammalia, Soricidae). Journal of Morphology 189: 25-43.

Green, G. and Sussman, R. W. 1990. Deforestation history of the eastern rainforests of Madagascar from satellite images. Science 248: 212-215.

Harcourt, C. and Thornback, J. 1990. Lemurs of Madagascar and the Comoros. The IUCN Red Data Book. IUCN, Gland, Switzerland and Cambridge, UK.

Irwin, M. T., Johnson S. E. and Wright P. C. 2005. The state of lemur conservation in south-eastern Madagascar: population and habitat assessment for diurnal lemurs using surveys, satellite imagery and GIS. Oryx 39, 2: 204-218.

Johnson, S. E. and Overdorff, D. J. 1999. Census of brown lemurs (Eulemur fulvus spp.) in south-eastern Madagascar: Methods-testing and conservation implications. American Journal of Primatology 47: 51-60.

Johnson, S. E. and Wyner, Y. 2000. Notes on the biogeography of Eulemur fulvus cinereiceps. Lemur News 5: 25-28.

Johnson, S. E., Lei, R., Martin, S. K., Irwin, M. T. and Louis, E. E. 2008. Does Eulemur cinereiceps exist? Preliminary evidence from genetics and ground surveys in southeastern Madagascar. American Journal of Primatology 70: 372-385.

Krebs, C. J. 2001. Ecology: The experimental analysis of distribution and abundance. 5th Edition. Benjamin Cunnings, San Francisco.

Mittermeier, R. A., Konstant, W. R., Hawkins, F., Louis, E. E., Langrand, O., Ratsimbazafy, J. H., Rasoloarison, R. M., Ganzhorn, J. U., Rajaobelina, S., Tattersall, I., and Meyers, D. 2006. Lemurs of Madagascar. 2nd Edition. Conservation International, Washington, D. C.

Moat, J. and Smith, P. 2007. Atlas of the vegetation of Madagascar. Royal Botanic Garden, Kew.

Overdorff, D. J. 1993. Similarities, differences, and seasonal patterns in the diets of Eulemur rubriventer and Eulemur fulvus rufus in the Ranomafana National Park, Madagascar. International Journal of Primatology 14: 721-753.

Petter, J. J. and Petter-Rousseaux, A. 1979. Classification of the prosimians, In: The Study of Prosimian Behaviour. G. A. Doyle and R. D. Martin (eds.), pp. 359-409. Academic Press, New York.

Ratsimbazafy, J. H. 2002. On the brink of extinction and the process of recovery: Responses of black-and-white ruffed lemurs (Varecia variegata variegata) to disturbance in Manombo forest, Madagascar. Unpub. Ph.D thesis, State University of New York at Stony Brook, Stony Brook.

Smith, A. P., Horning, N., and Moore, D. 1997. Regional biodiversity planning and lemur conservation with GIS in western Madagascar. Conservation Biology 11: 498-512.

Sterling, E. J. and Ramaroson, M. 1996. Rapid assessment of the primate fauna of the eastern slope of the Réserve Naturelle Intégrale d'Andringitra, Madagascar, In: A floral and faunal inventory of the eastern slopes of the Réserve Naturelle Intégrale d'Andringitra, Madagascar: with reference to elevational variation. S. M. Goodman (ed.), pp. 293-305. Fieldiana Zoology, new series 85.

Stevens, N. J. 2003. The influence of substrate size, orientation and compliance upon prosimian arboreal quadrupedalism. Unpub. Ph.D. thesis, State University of New York at Stony Brook.

Stevens, N. J., Schmitt, D. O., Cole, T. M. and Chan, L.-K. 2006. Technical note: Out-of-plane angular correction based on a trigonometric function for use in two-dimensional kinematic studies. American Journal of Physical Anthropology 129: 399-402.

Tattersall, I. 1982. The primates of Madagascar. Columbia University, New York.

Weber, E. 2003. Invasive Plant Species of the World. A Reference Guide to Environmental Weeds. CABI Publishing, UK.

Wright, P. 1997. The future of biodiversity in Madagascar: A view from Ranomafana National Park, In: Natural Change and Human Impact in Madagascar. S. M. Goodman and B. D. Patterson (eds.), pp. 381-405. Smithsonian Institution Press, Washington, D. C. 